\title{
PROTEIN PROFILE ANALYSIS BY SDS-PAGE OF MYCOPLASMA GALLISEPTICUM STRAINS S6(208) AND F-K810 GROWN IN HAYFLICK'S AND FREY'S MEDIA
}

\author{
Priscila N. Ferraz'; ; Claudio C. P. Menezes ${ }^{1}$; Maria das Graças M. Danelli ${ }^{1 *}$; Jackeline de O. P. Lizeu ${ }^{1}$; \\ Elmiro R. do Nascimento²; Daniela M. Lucchesi ${ }^{3}$. \\ ${ }^{1}$ Instituto de Veterinária, Universidade Federal Rural do Rio de Janeiro, Seropédica, RJ, Brasil; ${ }^{2}$ Faculdade de \\ Veterinária, Universidade Federal Fluminense, Niterói, RJ, Brasil. ${ }^{3}$ Instituto de Tecnologia em \\ Imunobiológicos/FIOCRUZ, Rio de Janeiro, RJ, Brasil.
}

Submitted: March 02, 1999; Returned to authors for corrections: July 27, 1999; Approved: June 26, 2000

\section{SHORT COMMUNICATION}

\begin{abstract}
The Mycoplasma gallisepticum strains [wild-type S6 (208) and a vaccine-type F-K810] grown in Frey's and Hayflick's media were analyzed by SDS-PAGE. No visual changes in the protein profiles of these strains were observed regardless of the media composition used, although the polyacrylamide gel electrophoretograms showed minor differences do exist when densitometer traces of the gel are compared. Both strains were easily differentiated on SDS-PAGE analysis by a peptide band p75, that is specific for MG F-K810 strain, used as vaccine.
\end{abstract}

Key words: Mycoplasma gallisepticum, SDS-PAGE, protein profile

Mycoplasma gallisepticum (MG) is considered the main cause of chronic respiratory disease (CDR) of chickens and infectious sinusitis of turkeys, causing important economic losses in the poultry breeders' (11). For controlling MG infection in commercial chickens layers it would be adequate to apply live MG vaccines (7).

Serologic tests are useful for monitoring the MG infection in a flock and for prophylactic measures to control MG infection early detected in MG free poultry. However, these tests showed low specificity and the sensibility depends on the test that had been chosen (1). In addition, elementary bacteria's composition varies even in the same specie, under different cultural media and conditions, causing different sets of protein expression and others important specific compounds for immune responses (2).

The goal of this study was to determine if the change of Frey culture medium by Hayflick's medium would induce some alterations in MG protein profiles.
The MG S6(208) and F-K810 strains were cloned three times as suggested by Tully, 1983 (10) and confirmed by PCR(8). The activated cultures of the cloned strains were inoculated in $100 \mathrm{ml}$ of modified Hayflick's or Frey's media. The cultures were incubated at $37^{\circ} \mathrm{C}$ and the cells were harvested by centrifugation at the beginning of the acidification of the media, and washed three times with $0,25 \mathrm{M}$ saline buffer, $\mathrm{pH} 7.2$ (6,000 $\mathrm{xg} / 30$ minutes $\left./ 4^{\circ} \mathrm{C}\right)$. The protein concentration from each batch of washed cells was determined as described by Lowry et al., 1951 (6). Suspensions of $15 \mu \mathrm{g}$ of protein and molecular mass standards (Pharmacia) were solubilized with the same volume of sample buffer. The proteins samples were boiled for 5 minutes before electrophoresis and the proteins were fractionated by sodium dodecyl sulfate-polyacrylamide gel electrophoresis (SDS-PAGE) with $10 \%$ (wt/vol.) of acrylamide/bis $37.5 \%$ gels (5). Protein electrophoretic profiles in gels were stained with Coomassie Blue R-250 and the bands were scanned using a

\footnotetext{
* Corresponding author. Mailing Address: Departamento de Microbiologia e Imunologia Veterinária, Instituto de Veterinária, Universidade Federal Rural do Rio de Janeiro, Antiga Rodovia Rio-São Paulo, Km 47, CEP 23890-000, Seropédica, RJ, Brasil. E-mail: danelli@ufrrj.br
} 
densitometer (Pharmacia System, Image-master 1D software). It was calculated the relative mobility estimates of proteins from each MG strain pattern based on the migration rate of the standard. Protein profiles from the same gel of MG strains grown in modified Hayflick's and Frey's media were compared.

The protein electrophoresis of whole cell yielded about 15 bands per strain (Fig.1). Each profile showed characteristic bands as previously reported $(2,3,4)$. MG F-K810 strain was consistent showing the protein about $75 \mathrm{KDa}$ (p75) used for identification in modified Hayflick's and Frey's media. The presence of p75 confirms the identification of MG F-vaccine strain, commonly used in breeders (3). In addition, the p75 was not detected in the MG S6 (208) strain regardless of the media that had been used. Ferreira Neto and Yamamoto, (2) noticed consistent differences in protein profiles of the strain F-K810 and S6 (208), grown either in Frey's medium with swine serum or TP's medium with horse serum, although the culture from Frey's medium to be more accurate in the differentiation of the protein profile. In addition, the authors reported a $75 \mathrm{KDa}$ protein, also detected from cultures of MG grown in TP medium, but not in Frey's medium.

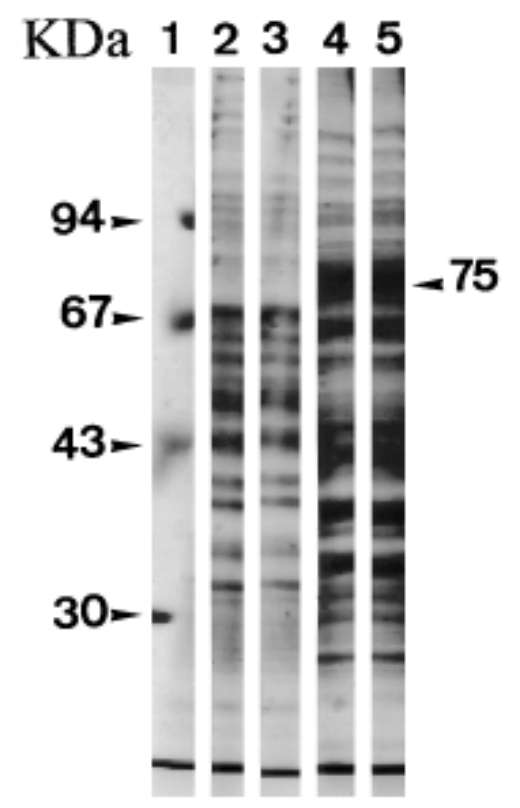

Figure 1: SDS-PAGE of proteins from two strains of Mycoplasma gallisepticum grown in modified Hayflick's and Frey's media. Lane 1, molecular mass standards (Pharmacia); Lane 2, MG S6(208) from Hayflick's medium; Lane 3, MG S6(208) from Frey's medium; Lane 4, MG F-K810 from Hayflick's medium; Lane 5, MG F-K810 from Frey's medium. p75 band.

Although in this survey had not showed differences in the protein profiles of MG S6 (208) and MG F-K810 strains, regardless of the media composition used, the polyacrylamide gel electrophoretograms showed that small differences do exist when densitometer gel's traces were compared (Fig.2). If them are able to cause antigenic changes that could interfere in the serological tests, it is necessary a further analysis of MG antigens with a lot of sera.
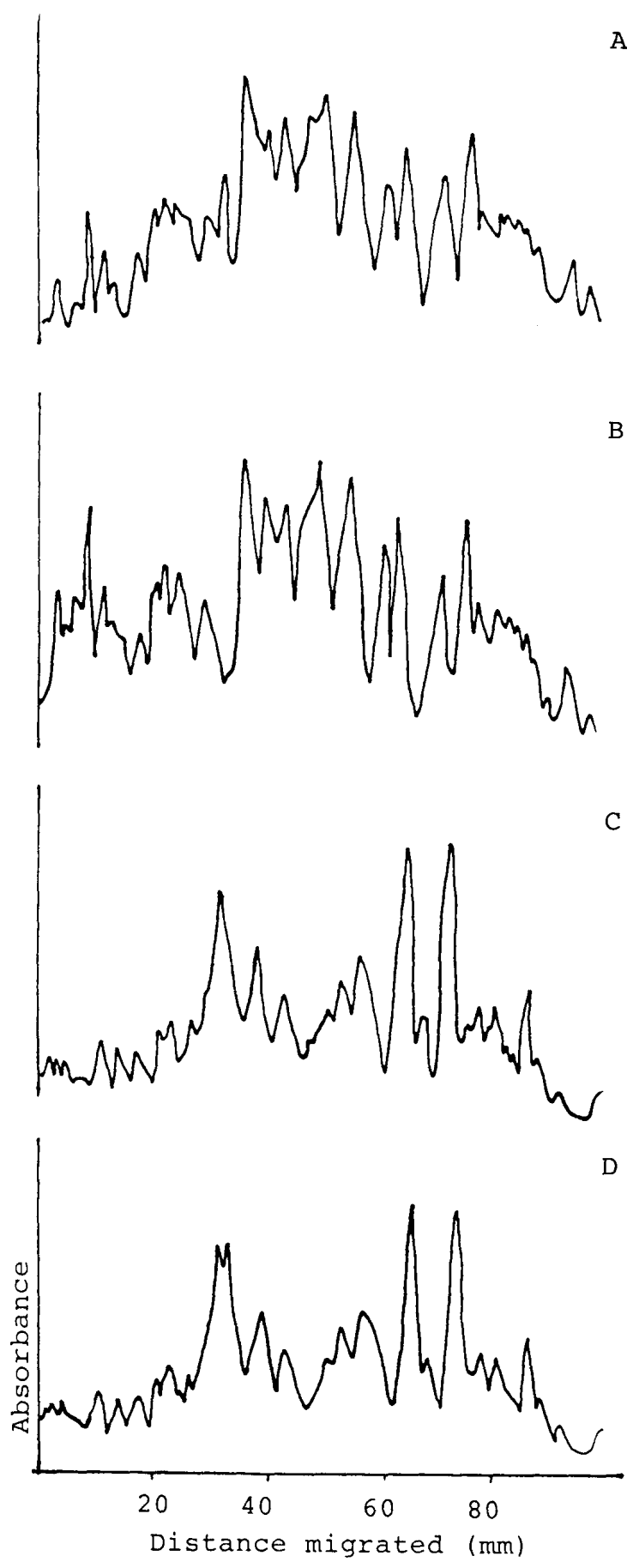

Figure 2: Densitogram of stained proteins from MG S6 (208) grown in Hayflick's medium (A) and Frey's medium (B) and MG F-K810 grown in Hayflick's medium (C) and Frey's medium (D) strains after separation on a $10 \%$ polyacrylamide gel. 
Variations in expression of some membrane protein may produce casual mistakes in serological tests and several authors have described MG infection in chickens and turkeys, where the antibody response is not detected readily by the agglutination and hemagglutination-inhibition tests for antigens prepared from standard reference strains (9). These results can confirm the rise of variant strains of $\mathrm{MG}$ or antigenic changes in the reference strain that had been used for antigen production.

\section{ACKNOWLEDGMENTS}

We wish to thanks CNPq and FAPERJ for partial financial support.

\section{RESUMO}

\section{Análise do perfil protéico das amostras Mycoplasma gallisepticum S6(208) e F-K810 cultivadas em meio de Hayflick e Frey, por SDS-PAGE}

Culturas de Mycoplasma gallisepticum [cepa selvagem S6(208) e vacina F-K810] cultivadas em meio de Frey e Hayflick foram analisadas por SDS-PAGE. Não houve alteração visual nos perfis protéicos das cepas utilizadas, apesar da mudança dos constituintes dos meios. Todavia, a análise por densitometria revelou diferenças menores. A amostras foram facilmente diferenciadas por SDS-PAGE, através da presença da banda peptídica p75, específica da cepa MG F-K810, usada como vacina.
Palavras-chave: Mycoplasma gallisepticum, SDS-PAGE, perfil protéico

\section{REFERENCES}

1. Abdelmoumen, B.B.; Ray, R.S. Antigenic relatedness among seven avian Mycoplasma species as revealed by Western Blot analysis. Avian Dis. 39: 250-262, 1995.

2. Ferreira Neto, S.M.; Yamamoto, R. Effect of media and incubation periods on Mycoplasma gallisepticum strains differentiation by SDS-PAGE protein analysis. Arq. Bras. Med. Vet. Zootec. 45: 543-556, 1993.

3. Gibbs, P.S.; Kleven, S.H.; Jackwood, M.W. Analysis and characterization of Mycoplasma gallisepticum isolates from Pennsylvania. Avian Dis. 38: 475-482, 1994.

4. Khan, M. I.; Lam, K.M.; Yamamoto, R. Mycoplasma gallisepticum strain variations detected by sodium dodecyl sulfate-polyacrylamide gel electrophoresis. Avian Dis. 31: 315-320, 1987.

5. Laemmli, U.K. Cleavage of structural proteins during the assembly of the head of bacteriophage T4. Nature (London). 227: 680-685, 1970.

6. Lowry, O. H.; Rosebrough, J.N.; Farr, A. L.; Randall, R. L. Protein measurement with folin phenol reagent. J. Biol. Chem. 193: 265-275, 1951.

7. Luginbuhl, R. E.; Tourtellote, M.E.; Frazier, M.N. Mycoplasma gallisepticum - Control by immunization. Ann. N.Y. Acad. Sci.43: 234 238, 1976.

8. Nascimento, E.R.; Yamamoto, R.; Herrick, K.R.; Tait, R.C. Polymerase chain reaction for detection of Mycoplasma gallisepticum. Avian Dis. 35: 62-69, 1991.

9. Stipkovits, L.; Kempf, I. Mycoplasmosis in poultry. Vet. Sci. Tech. Off. Int. Epiz. 15: 1495-1525, 1996.

10. Tully, J.G. Cloning and filtration techniques for Mycoplasmas. In: Razin, S.; Tully, J.G. (Eds). Methods in Mycoplasmology. Vol. 1. Academic Press, New York, 1983, p.173-177.

11. Yoder, H. W. Jr. Mycoplasmosis. In: Chairman, S.B.; Dormemuth, C.H.; Purchase, H.G.; Willians, J.E. (Eds). Isolation and identification of avian pathogens. American Association of Avian Pathologists, New York, 1980, p.40-42. 